\title{
Hemostatic risk factors in patients with coronary artery disease and type 2 diabetes - a two year follow-up of 243 patients Thomas W Jax*1,2,3, Ansgar J Peters ${ }^{1}$, Gunnar Plehn ${ }^{4}$ and Frank- Chris Schoebel ${ }^{1}$
}

Address: ${ }^{1}$ Medizinische Klinik und Poliklinik B, Klinik für Kardiologie, Pneumologie und Angiologie, Heinrich-Heine-Universität, Moorenstr. 5, 40225 Duesseldorf, Germany, ${ }^{2}$ Profil Institut für Stoffwechselforschung, Hellersbergstrasse 9, 41460 Neuss, Germany, ${ }^{3}$ Medizinische Klinik 3 , Klinik für Kardiologie, Herzzentrum Wuppertal, and Institut für Herz- und Kreislaufforschung, Dortmund, both Universität Witten/Herdecke, Germany and ${ }^{4}$ Medizinische Klinik II, Marienhospital Herne, Ruhr-Universität Bochum, Herne, Germany

Email: Thomas W Jax* - thomas.jax@profil-research.de; Ansgar J Peters - ap@kardiologiekoeln.de; Gunnar Plehn - gplehn@gmx.de; FrankChris Schoebel - schoebel@cardiopraxis.de

* Corresponding author

\section{Published: 7 September 2009}

Cardiovascular Diabetology 2009, 8:48 doi:10.1/86/1475-2840-8-48

This article is available from: http://www.cardiab.com/content/8/1/48

(c) 2009 Jax et al; licensee BioMed Central Ltd.

This is an Open Access article distributed under the terms of the Creative Commons Attribution License (http://creativecommons.org/licenses/by/2.0), which permits unrestricted use, distribution, and reproduction in any medium, provided the original work is properly cited.
Received: 20 July 2009

Accepted: 7 September 2009

\begin{abstract}
Backgound: Thrombosis is regarded to be a key factor in the development of acute coronary syndromes in patients with coronary artery disease (CAD). We hypothesize, that hemostatic and rheological risk factors may be of major relevance for the incidence and the risk stratification of these patients.
\end{abstract}

Methods: In 243 patients with coronary artery disease and stable angina pectoris parameters of metabolism, hemostasis, blood rheology and endogenous fibrinolysis were assessed. Patients were prospectively followed for 2 years in respect to elective revascularizations and acute coronary syndromes.

Results: During follow-up 88 patients presented with cardiac events, 22 of those were admitted to the hospital because of acute events, 5 Patients were excluded due to non- cardiac death. Patients with clinical events were found to be more frequently diabetic and presented with a more progressed coronary atherosclerosis. Even though patients with diabetes mellitus demonstrated a comparable level of multivessel disease (71\% vs. $70 \%)$ the rate of elective revascularization was higher $(41 \%$ vs. $28 \%, p<0.05)$. The results were also unfavorable for the incidence of acute cardiovascular events $(18 \%$ vs. $8 \%, \mathrm{p}<0.01)$. In comparison to non-diabetic patients diabetics demonstrated significantly elevated levels of fibrinogen $(352 \pm 76$ vs. $312 \pm 64 \mathrm{mg} / \mathrm{dl}, \mathrm{p}<0.0 \mathrm{l})$, plasma viscosity ( $\mathrm{I} .38 \pm 0.23$ vs. I $.3 \mathrm{I} \pm 0.16 \mathrm{mPas}, \mathrm{p}<0.0 \mathrm{I})$, red blood cell aggregation ( $13.2 \pm 2.5$ vs. I $2 . \mathrm{I} \pm 3 . \mathrm{I} \mathrm{E}, \mathrm{p}<0.05)$ and plasmin-activator-inhibitor $(6 . \mathrm{II} \pm 3.4$ vs. $4.7 \pm 2.7 \mathrm{U} / \mathrm{l}, \mathrm{p}<0.05)$.

Conclusion: Pathological alterations of fibrinogen, blood rheology and plasminogen-activatorinhibtor as indicators of a procoagulant state are of major relevance for the short-term incidence of cardiac events, especially in patients with diabetes mellitus type 2 , and may be used to stratify patients to specific therapies. 


\section{Introduction}

Apart from established, traditional cardiovascular risk factors like e.g. hypercholesterolemia, parameters of hemostasis, endogenous fibrinolysis and platelet activity are more and more recognized of being of importance in the pathogenesis of atherosclerosis and acute coronary syndromes especially in diabetic patients [1-9].

A recent study could show a diabetic specific coronary morphology that is strongly related to hemostasis and rheology [10]. Both parameters of endogenous fibrinolysis and markers of platelet activity showed a relevant association on the extent of coronary sclerosis. The metabolic changes with consecutive dysbalances of platelet activity, hemostasis and endogenous fibrinolysis, and rheology favor a prothrombotic milieu. These systemic changes may result in an increased, thrombosis driven atherosclerotic process [11], in part explaining the advanced coronary plaque burden and in particular the more distal pronounced distribution of coronary atherosclerosis in patients with diabetes mellitus.

The potential role of these parameters for cardiovascular events was shown in large epidemiological studies [12]. Coronary thrombosis is thought to play a major role for the pathogenesis of acute coronary syndromes [13]. Therefore parameters indicating and predisposing arterial thrombosis might be of major relevance for the higher rate of cardiovascular events in patients with diabetes mellitus.

The present study characterizes the cardiovascular risk profile of 243 patients evaluating the influence on the occurrence of cardiovascular events. Besides of traditional cardiovascular risk factors, parameters of hemostasis, endogenous fibrinolysis and blood rheology were assessed.

\section{Methods}

The study included a total of 264 consecutive patients with CAD undergoing elective coronary angiography either for suspected CAD or with suspected progression of known CAD. Key exclusion criteria were unstable angina pectoris, myocardial infarction within the last two months, acute or chronic heart failure (NYHAIII or IV), severe chronic and acute infection and malignant tumors.

With the beginning of the study the patients gave their informed consent to additional blood sampling during the routine investigation. The patients were informed in detail about the aims of the study and that a follow up was planned. After two years telephone interviews were carried out. If patients could not be contacted by telephone or at their addresses, their relatives or their general practitioners were contacted. As dependent variables for the follow- up period of two years the occurrence of the following events were examined: unstable angina pectoris, myocardial infarction, cardiac death, non- cardiac death, elective PTCA or ACB operation and acute cardiovascular revascularization. In case of present unstable angina pectoris, stable but severe functional limitations of patients or an inadequate medication, the interviewer contacted the general practitioner for further information.

\section{Definition of the cardiovascular risk profil}

Hypercholesterolemia was presupposed with total cholesterol above $220 \mathrm{mg} / \mathrm{dl}$, with a positive history of hypercholesterolemia and/or with lipid reducing therapies. The same was assumed for hypertriglyceridemia above 200 $\mathrm{mg} / \mathrm{dl}$. Thus dyslipoproteinemia was diagnosed when hypercholesterolemia or hypertriglyceridemia occured. Hypertension was defined in patients with a resting blood pressure above systolic $140 \mathrm{mmHg}$ or diastolic $90 \mathrm{mmHg}$, with a history of hypertension or with antihypertensive medication. Nicotin consumption was assessed by history. Diabetes was defined by fasting plasma glucose concentration above $126 \mathrm{mg} / \mathrm{dl}$ or an antidiabetic therapy. Recent studies suggest, that a high percentage of cardiac patients present with newly diagnosed type 2 diabetes by use of oral glucose tolerance tests (OGTT) [14-16]. OGTT was not part of this protocol; therefore the true rate of diabetes may be underestimated.

\section{Coronary Angiography}

In all patients coronary angiograms with imaging of the coronary arteries in different standardized projections were carried out. The degree of coronary artery stenosis was assessed by two experienced, independent examiners. The severity of CAD was defined as coronary 1,2 or 3 vessel disease corresponding to the number of affected main vessels with hemodynamic relevant stenosis above $50 \%$. Extent of coronary sclerosis was determined by a special grading system in accordance with an evaluation system of the American Heart Association [17]. Based on these findings the coronary artery system was divided into 15 segments. The segment with a higher degree of stenosis got a higher score. The sum of these scores was divided by the number of judged segments. The result presents the extent of coronary atherosclerosis. To get information about the distribution pattern of coronary sclerosis a proximal score was calculated from the proximal segments and a distal score was calculated from the distal segments of the coronary arteries and of first degree branches.

\section{Laboratory methods}

Blood samples for the different studies were taken at the day of cardiac catheterization between 7:00 and 8:00 am according to a standardized protocol. Before venous puncture was performed patients had spent a rest period in lying position for 30 minutes. Venous puncture of an 
antecubital vene was done with a butterfly canula after a maximum venous congestion time of 30 seconds and a maximum congestion pressure of $40 \mathrm{mmHg}$. After decompression the first $4 \mathrm{ml}$ of blood were not used. Blood samples were sampled in vacutainer tubes. Samples were frozen at a temperature of minus $80^{\circ} \mathrm{C}$. For parameters of hemostasis and endogenous fibrinolysis tubes with 0.129 $\mathrm{M} \mathrm{Na}_{2}$ citrat were used. Determination of plasma viscosity and red blood cell aggregation was performed from EDTA tubes within 4 hours after sample taking. The samples were analyzed immediately after preparation or from deeply frozen plasma within three months after sample taking.

Plasma fibrinogen levels were determined according to method described by Clauss [18]. Plasmaviscosity was determined by capillary tube viscosimeter of Rheomed, Aachen (Germany). For determination of red blood cell aggregation an erythrocyte aggregometer (Myrenne, Roetgen, Germany) according to the method of SchmidSchönbein [19] was used. Plasma tissue plasminogenactivator antigen concentration was measured by enzymimmunoassay. Determination of Plasminogenactivator inhibitor activity was performed by chromogenic enzymassay.

\section{Statistical methods}

Statistical analyses were performed using SPSS software (Statistical Package for Social Sciences for Windows; SPSS 12, Munich). The results were tested for normal distribution by Kolmogoroff-Smirnoff test. For normally distributed parameters group comparison was made by use of paired and unpaired Student's t-test. Mann-Whitney UTest was used for non-normally distributed parameters. The Pearson correlation coefficient or the Spearman's rank correlations were used to describe the association between the variables in the study. Chi square test was used for comparison of non continuous data. Statistical significance was defined as $\mathrm{p}<0.05$.

\section{Results}

Out of 264 originally selected patients a clinical course after 2 years could be documented in 243 patients. Thus the feed back rate was $91.3 \%$. Patient characteristics are given in table 1 . Per definition in 150 patients there was no cardiovascular event. Three patients died from noncardiac disease. Within the follow up period 88 patients developed a cardiovascular event. 66 of them underwent elective revascularization (figure 1). Of those 44 underwent PTCA and 22 ACB bypass surgery. 22 patients suffered from an acute cardiovascular event: 11 from an

Table I: patient characteristics

\begin{tabular}{|c|c|c|c|}
\hline & $\begin{array}{c}\text { clinical event } \\
n=88\end{array}$ & $\begin{array}{l}\text { without clinical event } \\
\qquad n=150\end{array}$ & p - value \\
\hline age (in years) & $58 \pm 10$ & $56 \pm 11$ & n.s. \\
\hline Male (\%) & 85 & 84 & n.s. \\
\hline \multicolumn{4}{|l|}{ risk profile } \\
\hline hypertension (\%) & 59 & 52 & n.s. \\
\hline diabetes mellitus & 31 & 11 & $<0,001$ \\
\hline hyperlipidemia (\%) & 78 & 78 & n.s. \\
\hline hypercholesterinemia (\%) & 69 & 70 & n.s. \\
\hline hypertriglyceridemia (\%) & 29 & 32 & n.s. \\
\hline history of smoking or smoking (\%) & 69 & 66 & n.s. \\
\hline positive family history (\%) & 44 & 42 & n.s. \\
\hline \multicolumn{4}{|l|}{ Anamnese } \\
\hline history of myokardial infarction (\%) & 44 & 51 & n.s. \\
\hline history of ACB operation (\%) & 10 & 5,4 & n.s. \\
\hline history of PTCA (\%) & 57 & 61 & n.s. \\
\hline \multicolumn{4}{|l|}{ Medication } \\
\hline nitrates (\%) & 87 & 80 & n.s. \\
\hline calcium channel blockers (\%) & 50 & 41 & n.s. \\
\hline betablockers (\%) & 41 & 46 & n.s. \\
\hline ace-inhibitors (\%) & 31 & 28 & n.s. \\
\hline thrombocytaggregationinhibitors (\%) & 73 & 78 & n.s. \\
\hline lipid lowering medication (\%) & 37 & 45 & n.s. \\
\hline insuline (\%) & $\mathrm{I}, \mathrm{I}$ & $\mathrm{I}, 4$ & n.s. \\
\hline oral andiabetic medication (\%) & 10 & 3,4 & $p<0,05$ \\
\hline
\end{tabular}




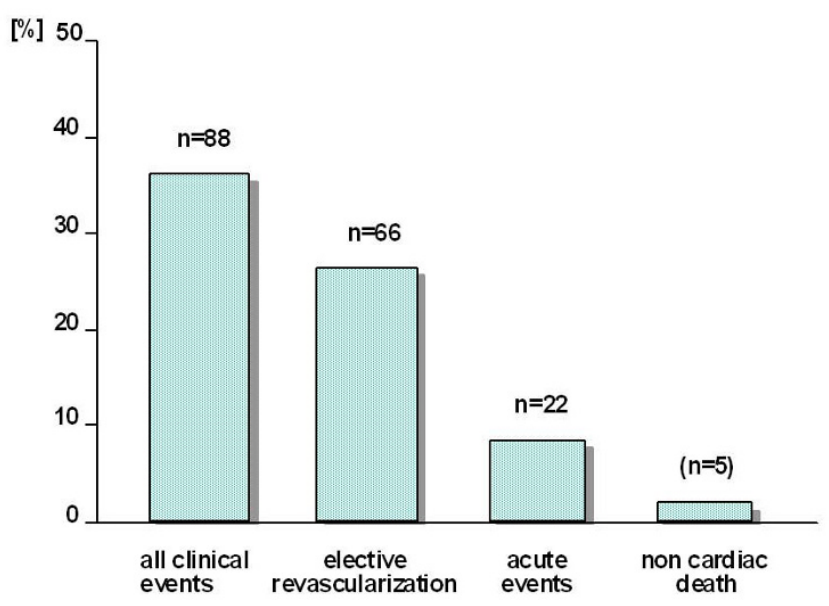

Figure I

clinical events in $\mathbf{2 4 3}$ patients. Elective revascularizations include aorto-coronary bypass operation and angioplasty, acute events include unstable angina pectoris, acute myocardial infarction and cardiac death.

unstable angina pectoris, 8 from an acute myocardial infarction and 3 from a cardiac death. Related to the observed group $(n=241)$ these figures correspond to an elective rate of revascularization of 27,3\% (PTCA, ACB) and to an acute rate of events of $9,1 \%$.

In regard to the characterization of patients those with coronary ischemic event differed from those without an event by a higher share of diabetic patients (see table 1).

\section{Severity and extend of CAD}

In assessing the severity and extend of coronary sclerosis it became clear that there was a bigger share of coronary multiple vessel disease (72\%) in the group with clinical event than in the group without clinical event (49\%). These results showed that the increased severity of CAD also resulted in a higher extend of coronary sclerosis which was reflected in proximal as well as distal distribution of coronary sclerosis (table 2)

\section{Metabolic risk factors}

There was no significant difference between the two groups with regard to metabolic risk factors. Only blood glucose discriminated which can be explained by the high prevalence of diabetic patients with a clinical event in this group (table 3 ).

\section{Parameter of hemostasis and blood rheology}

No difference could be found between the two groups with regard to fibrinogen levels and rheological parameters. Parameters of endogeneous fibrinolysis showed a significant increase of tissue-plasminogen-activator in those patients who suffered from a clinical event in the follow up period (table 3 ).

\section{Patients with diabetes mellitus}

Cardiovascular events were significantly higher in the group of diabetic patients with $64 \%$ compared to $31 \%$ in the non- diabetic patients (figure 2). Even though patients with DM demonstrated a comparable level of multivessel disease in comparison to controls ( $71 \%$ vs. $70 \%$ ) the rate of elective revascularization was higher $(41 \%$ vs. $28 \%$, p < $0.05)$. The share of elective revascularization procedures was higher in the group of nondiabetic patients, if only the patients with an event were calculated (80\% vs. $64.3 \%$, p < 0.05). Three cardiac deaths in the non- diabetic group and no death in the diabetic patients did not show significance. The results were also unfavorable for the incidence of acute cardiovascular events (18.3\% vs. $28.6 \%, \mathrm{p}<0.01)$.

\section{Metabolic and hemostatic parameters}

Due to a significant higher rate of cardiovascular events in diabetic patients we further evaluated the metabolic and hemostatic differences between patients with and without diabetes mellitus (table 4 and figure 3). Diabetic patients presented with lower HDL and higher LDL and triglyceride- levels (see table 4). We did not assess long-term metabolic control with HbA1c. Although tissueplasminogenactivator was comparable between the 2 groups, plasminogen- activator- inhibitor was higher in

Table 2: severity and extent of coronary atherosclerosis

\begin{tabular}{|c|c|c|c|}
\hline & $\begin{array}{c}\text { clinical event } \\
n=88\end{array}$ & $\begin{array}{l}\text { without clinical event } \\
\qquad n=150\end{array}$ & p-value \\
\hline \multicolumn{4}{|c|}{ severity of coronary artery disease } \\
\hline I- vessel disease (\%) & 28 & 51 & \\
\hline 2 - vessel disease (\%) & 36 & 28 & \\
\hline 3 - vessel disease (\%) & 36 & 22 & $P<0,01$ \\
\hline \multicolumn{4}{|c|}{ extent of coronary atherosclerosis } \\
\hline total score & $1,67 \pm 0,71$ & $1,31 \pm 0,73$ & $\mathrm{P}<0,001$ \\
\hline proximal score & $1,83 \pm 0,74$ & $1,49 \pm 0,77$ & $p<0,001$ \\
\hline distal score & $1,43 \pm 0,79$ & $1,03 \pm 0,70$ & $p<0,001$ \\
\hline
\end{tabular}


Table 3: parameters of metabolism, hemostasis endogenous fibrinolysis and blood rheology

\begin{tabular}{|c|c|c|c|}
\hline & $\begin{array}{c}\text { clinical event } \\
n=88\end{array}$ & $\begin{array}{l}\text { without clinical event } \\
\qquad n=150\end{array}$ & p-value \\
\hline total cholesterol (mg/dl) & $243 \pm 49$ & $238 \pm 44$ & n.s. \\
\hline hdl - cholesterol(mg/dl) & $44 \pm 11$ & $45 \pm 12$ & n.s. \\
\hline $\mid \mathrm{Il}$ - cholesterol(mg/dl) & $182 \pm 49$ & $|73 \pm 4|$ & n.s. \\
\hline triglycerides (mg/dl) & $209 \pm 143$ & $185 \pm 113$ & n.s. \\
\hline lipoproteine (a) (mg/dl) & $32 \pm 39$ & $34 \pm 41$ & n.s. \\
\hline uric acid $(\mathrm{mg} / \mathrm{dl})$ & $5,8 \pm 1,6$ & $6,6 \pm 1,7$ & n.s. \\
\hline glucose $(\mathrm{mg} / \mathrm{dl})$ & $108 \pm 51$ & $92 \pm 35$ & $<0,05$ \\
\hline tissue -plasminogenactivator $(\mu \mathrm{g} / \mathrm{l})$ & $9,3 \pm 3,5$ & $8,2 \pm 3,0$ & $<0,05$ \\
\hline plasminogenaktivator-inhibitore $(\mathrm{U} / \mathrm{ml})$ & $4,9 \pm 2,5$ & $4,9 \pm 3,0$ & n.s. \\
\hline fibrinogen (mg/dl) & $330 \pm 65$ & $319 \pm 70$ & n.s. \\
\hline plasma viscosity $\left(\mathrm{mPa} \times \mathrm{s}^{-1}\right)$ & $\mathrm{I}, 3 \pm 0, \mathrm{I}$ & $\mathrm{I}, 3 \pm 0,2$ & n.s. \\
\hline red blood cell aggregation $M(E)$ & $7,7 \pm 2,4$ & $7,5 \pm 2,3$ & n.s. \\
\hline red blood cell aggregation $\mathrm{MI}(\mathrm{E})$ & $12,4 \pm 2,9$ & $12,3 \pm 3,0$ & n.s. \\
\hline hematocrit (\%) & $43,6 \pm 3,2$ & $43, I \pm 3,1$ & n.s. \\
\hline
\end{tabular}

diabetic patients. Parameters of blood rheology were all elevated in the group of patients with diabetes mellitus (see figure 3).

\section{Discussion}

The presented results on the influence of rheological parameters and factors of endogenous fibrinolysis on the rate of clinical events showed that $t$-PA concentration is of predictive importance within a follow up period of two years. As the clinical rate of events in this study is essentially determined by elective revascularisation the increase of tPa in our study does not reflect so much the influence on acute clinical events but points to the correlation between tPa and severity and extend of coronary sclerosis, respectively. The incidence of acute coronary events was $9.1 \%$ within the two year- period and thus roughly corresponds to the estimated figure of $2-5 \%$ per year. Considering the share of patients with coronary multiple vessel

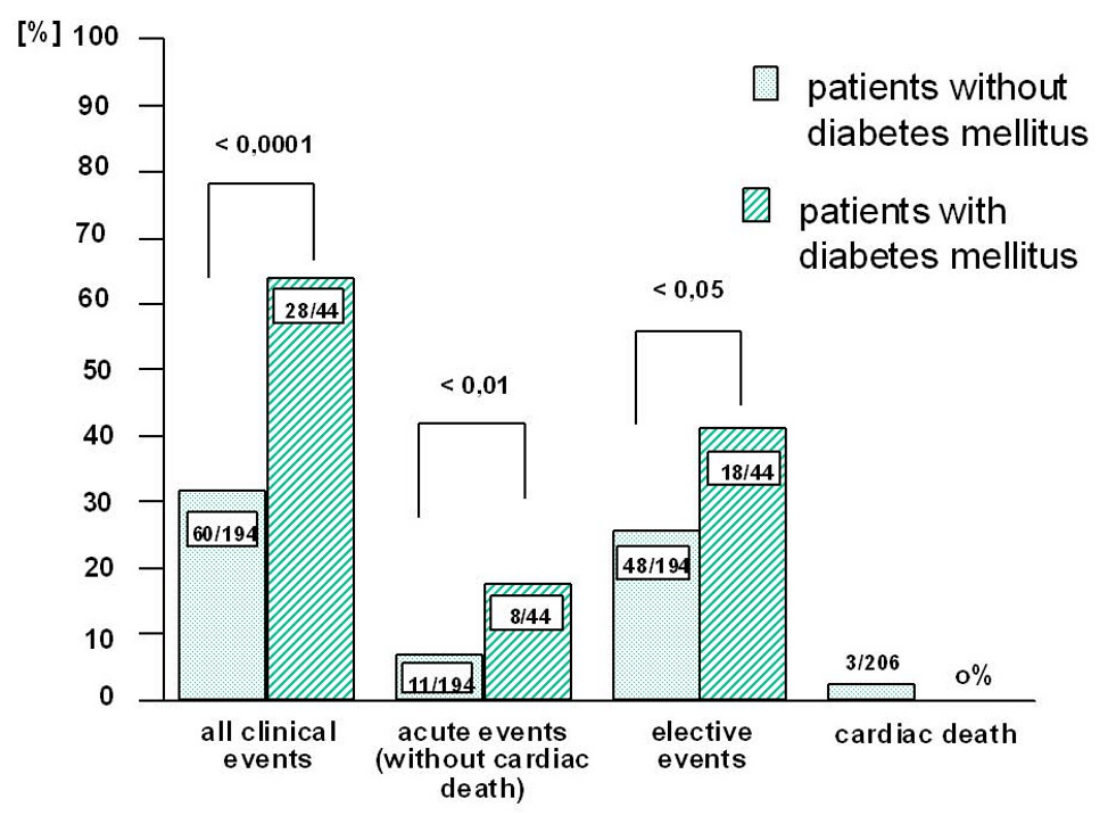

Figure 2

clinical events for patients with and without diabetes mellitus. Elective revascularizations include aorto-coronary bypass operation and angioplasty, acute events include unstable angina pectoris, acute myocardial infarction and cardiac death. 
Table 4: parameters of metabolism, hemostasis, endogenous fibrinolysis and blood rheology for patients with and without diabetes mellitus

\begin{tabular}{|c|c|c|c|}
\hline & $\begin{array}{c}\text { diabetes mellitus } \\
\qquad n=44\end{array}$ & $\begin{array}{c}\text { non-diabetic patients } \\
n=194\end{array}$ & p-value \\
\hline total cholesterol (mg/dl) & $254 \pm 69$ & $239 \pm 43$ & n.s. \\
\hline hdl - cholesterol(mg/dl) & $42 \pm 13$ & $45 \pm 12$ & $<0,05$ \\
\hline Idl - cholesterol(mg/dl) & $188 \pm 55$ & $173 \pm 43$ & $<0,05$ \\
\hline triglycerides $(\mathrm{mg} / \mathrm{dl})$ & $257 \pm 204$ & $183 \pm 103$ & $<0,05$ \\
\hline lipoproteine (a) (mg/dl) & $22 \pm 33$ & $36 \pm 42$ & $<0,05$ \\
\hline glucose (mg/dl) & $157 \pm 67$ & $88 \pm 12$ & $<0,0001$ \\
\hline tissue -plasminogenactivator $(\mu \mathrm{g} / \mathrm{I})$ & $8,9 \pm 3,7$ & $8,4 \pm 3,0$ & n.s. \\
\hline plasminogenaktivator-inhibitore $(\mathrm{U} / \mathrm{ml})$ & $6,1 \pm 5,2$ & $4,8 \pm 2,7$ & $<0,05$ \\
\hline fibrinogen (mg/dl) & $351 \pm 76$ & $312 \pm 64$ & $<0,01$ \\
\hline plasma viscosity $\left(\mathrm{mPa} \times \mathrm{s}^{-1}\right)$ & $1,38 \pm 0,23$ & $1,31 \pm 0,16$ & $<0,01$ \\
\hline red blood cell aggregation $M(E)$ & $8,7 \pm 2,1$ & $7,3 \pm 2,0$ & $<0,05$ \\
\hline red blood cell aggregation $\mathrm{MI}(\mathrm{E})$ & $13,2 \pm 2,5$ & $\mid 2,1 \pm 3,1$ & $<0,05$ \\
\hline
\end{tabular}

disease of $57 \%$ the rate of revascularization with $27.3 \%$ is representative.

A disturbed endogenous fibrinolysis in diabetic patients has been described in the past $[4,9]$. The proportion of diabetics in the group with clinical events was relatively high. The increase of t-PA can be judged by an elevation of tPa - tPa inhibitor complexes and a consequently reduced fibrinolysis due to an increase in $\mathrm{tPa}$ - inhibitor concentration [12]. In addition, a high extend of atherosclerosis in coronary arteries and other vessel areas reflects a thrombogenic stimulus inducing a secondary, enhanced fibrinolytic activity. In a prior study from our group a parallel increase of t-PA and PAP complexes was measured and thus proved that an elevation of t-PA can reflect an increased fibrinolytic activity [20]. Factors of blood rheology had no predictive significance regarding the incidence of cardiovascular events. This may be explained by the fact that the described patients formed a group where coronary artery disease was manifest while the majority of epidemiological investigations on the prospective importance of fibrinogen were based on patients without any evidence of coronary artery disease [21]. Moreover the period of observation may have been to short and the clinical rate of event to small to give a valid statement.

Based on different prospective studies especially fibrinogen is considered as a proven hemostatic factor for an increased cardiovascular risk. A metaanalysis demonstrated a 2.3 fold elevated cardiovascular risk for fibrinogen levels above $320 \mathrm{mg} / \mathrm{dl}$ [21]. In addition to an impairment of hemostasis, blood rheology and platelet reactivity and the consequent imbalance of the hemostatic system (figure 4); fibrinogen may directly promote atherogenesis [21].
Apart from patients with hyperfibrinogenemia there were also patients with elevated t-PA and von Willebrand factor with an increased rate of cardiovascular events affected [12]. Other studies also found an elevated t-PA concentration as a risk factor of increased incidence of cardiovascular events. Data from the Physicians Health Study showed a 2.8 fold increased risk between lowest and highest quintile of t-PA concentration [22]. The importance of PAI is underlined by a follow up study of men after primary myocardial infarction. Those patients who showed elevated PAI concentrations as a sign of reduced fibrinolysis were at increased risk of reinfarction $[23,24]$. High concentrations of von Willebrand factor antigen are supposed to be markers of endothelial lesions and present a procoagulative mechanism due to an inhanced platelet adhesion [25].

The subset of patients with diabetes mellitus showed a marked increase in the number of cardiovascular events, favoring especially the number of acute events. This is in correspondence to the literature, which reports also a higher incidence of acute cardiovascular events like acute myocardial infarction and cardiac death [26] and also a higher incidence of revascularization procedures [27]. The potential role of insulin in atherogenesis has been discussed for 25 years [28]. Results of various prospective studies indicated that elevated plasma insulin levels cause and enhance atherosclerosis [29-31]. Diverse diseases associated with hyperinsulinemia like the metaboliv syndrome, hypertension, adipositas and hypertriglyceridemia show an early and extended manifestation of atherosclerosis [32-37]. Several studies proved that elevated insulin levels are accompanied by reduced endogenous fibrinolysis $[1-3,5,7]$. On the one hand hyperinsulinemia is associated with a decreased t-PA con- 

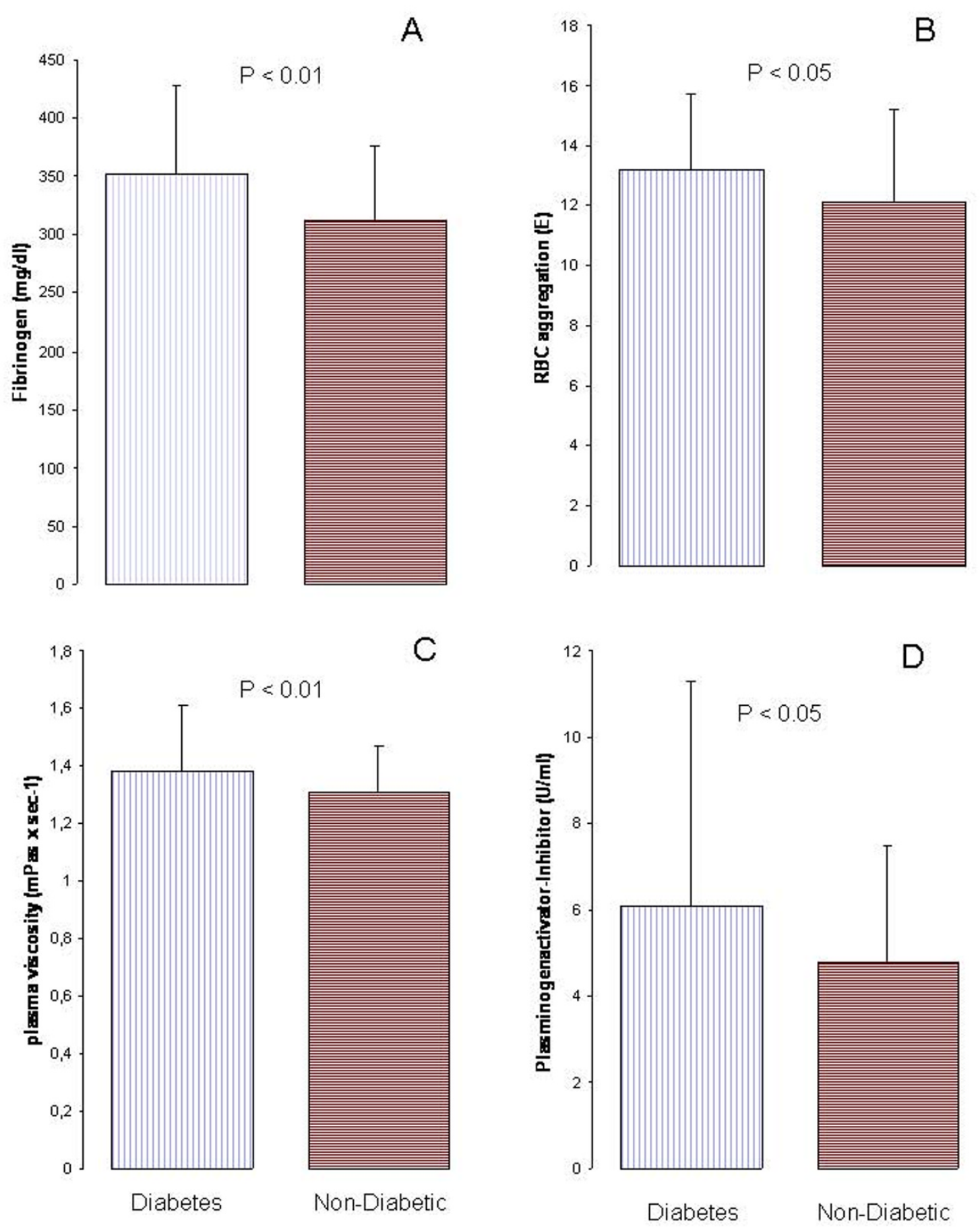

\section{Figure 3}

Rheology in diabetic patients. Between Patients with and without type 2 diabetes mellitus significant differences were found for fibrinogen $(\mathbf{A})$, red blood cell $(\mathrm{RBC})$ aggregation $(\mathbf{B})$, plasma viscosity $(\mathbf{C})$ and Plasminogenactivator-Inhibitor (PAI) (D). 


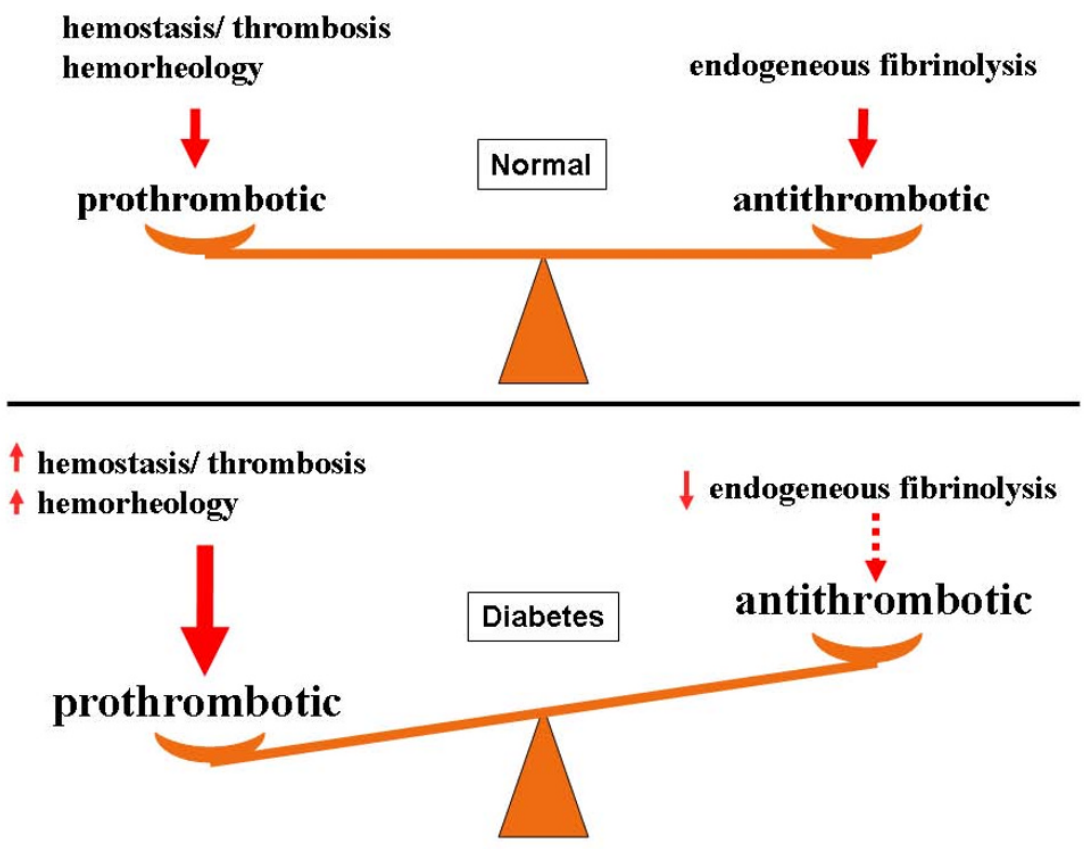

Figure 4

Balance and dysbalance of hemostasis in diabetes.

centration [5], on the other hand it causes an increase of PAI activity $[1-3,7]$.

Rheological properties in general are a major factor determining microcirculatory function and blood flow. Plasma viscosity and red blood cell aggregation are decisive rheological parameters of microcirculation. Erythrocyte aggregation is described to be closely linked to fibrinogen and alpha2- macroglobulin [38]. A fibrinogen mediated increase of both is not relevant in non- obstructed epicardial arteries under normal circumstances. Impaired blood rheology can restrict coronary blood flow and cause critically myocardial oxygen and nutrition supply in the area of poststenotic microcirculation of successive multiple linked stenoses and collateralized occlusions with heavily impaired vasomotion [39]. Diabetic patients present with impaired hemorheology, as also shown in this study. Patients with diabetes mellitus and stroke have more often an impaired hemorheology as non-diabetic patients [40]. Secondary microcirculatory complications are also associated with higher erythrocyte aggregation and viscosity [41].

Hemorheological disorders are strongly related to metabolic control (HbA1c), lipid parameters and hyperinsulinemia $[42,43]$. Red blood cell deformability is mediated by nitric oxide, as well as red blood cell aggregation [44]. Nitric oxide is well known to be markedly reduced in patients with type 2 diabetes mellitus and well accepted as a marker of endothelial function. Thus, the rheological impairment of diabetic patients is related to endothelial dysfunction and a possible cause of both micro- and macrovascular complications.

\section{Conclusion and Future Perspective}

In summary, pathological alterations of fibrinogen, blood rheology and plasminogen-activator-inhibtor as indicators of a procoagulant state (figure 4) are of relevance for the short-term incidence of cardiac events, especially in patients with diabetes mellitus type 2. Diabetes predisposes to those multiple alterations, which in turn can have multiple effects on atherosclerosis, vascular morphology and cardiovascular events. The possible link between endothelial dysfunction, red blood cell function and pathological rheology and hemostasis may, in part, connect micro- and macrovascular complications with diabetes mellitus. More research is needed to elucidate these potential mechanisms and possibly develop a tailored therapy for these diabetes specific mechanisms of atherothrombotic disease.

\section{Competing interests}

The authors declare that they have no competing interests.

\section{Authors' contributions}

TJ participated in the design and coordinated the study, performed the statistical analysis and drafted the manuscript. AP coordinated the study, and drafted the manu- 
script. GP coordinated the study and drafted the manuscript. FS participated in the design and coordinated the study, and drafted the manuscript. All authors read and approved the final manuscript.

\section{Acknowledgements}

This paper was in part presented as a poster at the Meeting of the American Diabetes Association 2009 in New Orleans, USA (Diabetes 58, Suppl. I: Al83 (2009)

\section{References}

I. Auwerx J, Bouillon R, Collen D, Geboers J: Tissue-type plasminogen activator antigen and plasminogen activator inhibitor in diabetes mellitus. Artherosclerosis 1988, 8:68-72.

2. Fisher BM, Quin JD, Rumley A, Lennie SE, Small M, MacCuish AC, Lowe GD: Effects of acute insulin-induced hypoglycaemia on haemostasis, fibrinolysis and haemorheology in insulindependent diabetic patients and control subjects. Clin Sci Colch I991, 80:525-53I.

3. Juhan Vague I, Alessi MC: activator inhibitor I and atherothrombosis. Thromb Haemost 1993, 70:138-143.

4. Schneider DJ, Nordt TK, Sobel BE: Attenuated fibrinolysis and accelerated atherogenesis in type II diabetic patients. Diabetes 1993, 42:1-7.

5. Eliasson M, Asplund K, Evrin PE, Lindahl B, Lundblad D: Hyperinsulinemia predicts low tissue plasminogen activator activity in a healthy population: the Northern Sweden MONICA Study. Metabolism 1994, 43:I579-I586.

6. Agewall S, Fagerberg B, Attvall S, Ljungman S, Urbanavicius V, Tengborn L, Wikstrand J: Microalbuminuria, insulin sensitivity and haemostatic factors in non-diabetic treated hypertensive men. Risk Factor Intervention Study Group. J Intern Med I 995, 237:195-203.

7. Nordt TK, Sawa H, Fujii S, Sobel BE: Induction of plasminogen activator inhibitor type-I (PAI-I) by proinsulin and insulin in vivo. Circulation 1995, 91:764-770.

8. Brazionis L, Rowley K, Jenkins A, Itsiopoulos C, O'Dea K: Plasminogen activator inhibitor- $I$ activity in type 2 diabetes: a different relationship with coronary heart disease and diabetic retinopathy. Arterioscler Thromb Vasc Biol 2008, 28(4):786-9l.

9. Stegenga ME, Crabben SN van der, Levi M, de Vos AF, Tanck MW, Sauerwein HP, Poll T van der: Hyperglycemia stimulates coagulation, whereas hyperinsulinemia impairs fibrinolysis in healthy humans. Diabetes 2006, 55(6): $1807-12$.

10. Jax TW, Peters AJ, Plehn G, Schoebel FC: Relevance of hemostatic risk factors on coronary morphology in patients with diabetes mellitus type 2. Cardiovasc Diabetol 2009, 8:24.

II. Fuster V, Badimon L, Badimon J], Chesebro JH: The pathogenesis of coronary artery disease and the acute coronary syndromes (I). N Engl J Med I992, 326(4):242-50.

12. Thompson SG, Kienast J, Pyke SD, Haverkate F, Loo JC van de: Hemostatic factors and the risk of myocardial infarction or sudden death in patients with angina pectoris. European Concerted Action on Thrombosis and Disabilities Angina Pectoris Study Group [see comments]. N Engl J Med 1995, 332:635-64l.

13. Fuster $\mathrm{V}$, Badimon L, Badimon JJ, Chesebro JH: The pathogenesis of coronary artery disease and the acute coronary syndromes (2). N Engl J Med 1992, 326:310-318.

14. Norhammar A, Tenerz A, Nilsson G, Hamsten A, Efendíc S, Rydén L, Malmberg K: Glucose metabolism in patients with acute myocardial infarction and no previous diagnosis of diabetes mellitus: a prospective study. Lancet 2002, 359(9324):2|40-4.

I5. Lankisch M, Füth R, Gülker H, Lapp H, Bufe A, Haastert B, Martin S, Rathmann W: Screening for undiagnosed diabetes in patients with acute myocardial infarction. Clin Res Cardiol 2008, 97(10):753-9.

16. Lankisch $M$, Füth $R$, Schotes D, Rose B, Lapp H, Rathmann W, Haastert B, Gülker H, Scherbaum WA, Martin S: High prevalence of undiagnosed impaired glucose regulation and diabetes mellitus in patients scheduled for an elective coronary angiography. Clin Res Cardiol 2006, 95(2):80-7.
17. Austen WG, Edwards JE, Frye RL, Gensini GG, Gott VL, Griffith LS, McGoon DC, Murphy ML, Roe $B B$ : A reporting system on patients evaluated for coronary artery disease. Report of the Ad Hoc Committee for Grading of Coronary Artery Disease, Council on Cardiovascular Surgery, American Heart Association. Circulation 1975, 5 I (Suppl):5-40

18. Clauss A: Gerinnungsphysiologische Schnellmethode zur Bestimmung des Fibrinogens. Acta Haematol 1957, I 7:237-24 I.

19. Schmid-Schönbein H: Thrombose als Vorgang in "strömendem Blut": Wechselwirkungen fluiddynamischer, rheologischer und enzymologischer Ereignisse beim Ablauf von Thrombozytenaggregation und Fibrinpolymerisation. Hämostaseologie 1988, 8: I49-I73.

20. Stein D, Heins M, Schoebel FC, Pels K, Jax TW, Stiegler H, Reinauer $H$, Strauer BE, Leschke M: Activation of the fibrinolytic system in patients with coronary artery disease and hyperfibrinognemia. Thromb Haemostas 1997, 77:970-974.

21. Ernst E, Resch KL: Fibrinogen as a cardiovascular risk factor: a meta-analysis and review of the literature. Ann Intern Med 1993, I I 8:956-963.

22. Ridker PM, Vaughan DE, Stampfer MJ, Sacks FM, Hennekens CH: A cross-sectional study of endogenous tissue plasminogen activator, total cholesterol, HDL cholesterol, and apolipoproteins A-I, A-II, and B- I 00. Arterioscler Thromb 1993, I 3: I 587-I 592.

23. Hamsten A, de Faire U, Walldius G, Dahlen G, Szamosi A, Landou C, Blomback $M$, Wiman $B$ : Plasminogen activator inhibitor in plasma: risk factor for recurrent myocardial infarction. Lancet 1987, 2:3-9.

24. Hamsten A, Wiman B, de Faire U, Blomback M: Increased plasma levels of a rapid inhibitor of tissue plasminogen activator in young survivors of myocardial infarction. N Engl J Med 1985 , 3 13:1557-1563.

25. Jansson $\mathrm{JH}$, Nilsson TK, Johnson $\mathrm{O}$ : von Willebrand factor in plasma: a novel risk factor for recurrent myocardial infarction and death [see comments]. Br Heart J I99|, 66:35I-355.

26. Haffner SM, Lehto S, Rönnemaa T, Pyörälä K, Laakso M: Mortality from coronary heart disease in subjects with type 2 diabetes and in nondiabetic subjects with and without prior myocardial infarction. $N$ Engl J Med I998, 339(4):229-34.

27. Norhammar A, Tenerz A, Nilsson G, Hamsten A, Efendíc S, Rydén L, Malmberg K: Glucose metabolism in patients with acute myocardial infarction and no previous diagnosis of diabetes mellitus: a prospective study. Lancet 2002, 359(9324):2|40-4.

28. Stout RW: Insulin and atherosclerosis. Lancet 1969, 2:327-328.

29. Pyorala K: Diabetes and coronary heart disease. Acta Endocrinol Suppl Copenh 1985, 272:342.

30. Cullen K, Stenhouse NS, Wearne KL, Welborn TA: Multiple regression analysis of risk factors for cardiovascular disease and cancer mortality in Busselton, Western Australia-- $13-$ year study. J Chronic Dis 1983, 36:37I-377.

31. Fontbonne A, Tchobroutsky G, Eschwege E, Richards JL, Claude JR, Rosselin GE: Coronary heart disease mortality risk: plasma insulin level is a more sensitive marker than hypertension or abnormal glucose tolerance in overweight males. The Paris Prospective Study. Int J Obes 1988, I 2:557-565.

32. Swislocki AL, Hoffman BB, Reaven GM: Insulin resistance, glucose intolerance and hyperinsulinemia in patients with hypertension. Am J Hypertens 1989, 2:419-423.

33. Singer P, Godicke W, Voigt S, Hajdu I, Weiss M: Postprandial hyperinsulinemia in patients with mild essential hypertension. Hypertension 1985, 7:182-186.

34. DeFronzo RA: Insulin secretion, insulin resistance, and obesity. Int J Obes 1982, 6(SuppI I):73-82.

35. Modan M, Halkin H, Almog S, Lusky A, Eshkol A, Shefi M, Shitrit A Fuchs Z: Hyperinsulinemia. A link between hypertension obesity and glucose intolerance. J Clin Invest 1985, 75:809-817.

36. Grundy SM: Hypertriglyceridemia: mechanisms, clinical significance, and treatment. Med Clin North Am 1982, 66:519-535.

37. Orchard TJ, Becker DJ, Bates M, Kuller LH, Drash AL: Plasma insulin and lipoprotein concentrations: an atherogenic association? Am J Epidemiol 1983, I I 8:326-337.

38. Kirschkamp T, Schmid-Schönbein $H$, Weinberger A, Smeets $R$ : Effects of fibrinogen and alpha2-macroglobulin and their apheretic elimination on general blood rheology and rheological characteristics of red blood cell aggregates. Ther Apher Dial 2008, I2(5):360-7. 
39. Johnstone MT, Creager SJ, Scales KM, Cusco JA, Lee BK, Creager MA: Impaired endothelium-dependent vasodilation in patients with insulin-dependent diabetes mellitus. Circulation 1993, 88(6):25I0-6.

40. Momtselidze N, Mantskava M, Mchedlishvili G: Hemorheological disorders during ischemic brain infarcts in patients with and without diabetes mellitus. Clin Hemorheol Microcirc 2006, 35(I2):26I-4.

4I. Mantskava M, Momtselidze N, Pargalava N, Mchedlishvili G: Hemorheological disorders in patients with type I or 2 diabetes mellitus and foot gangrene. Clin Hemorheol Microcirc 2006, 35(I2):307-10.

42. Zilberman-Kravits D, Harman-Boehm I, Shuster T, Meyerstein N Increased red cell aggregation is correlated with $\mathrm{HbAIC}$ and lipid levels in type $\mathbf{I}$ but not type 2 diabetes. Clin Hemorheol Microcirc 2006, 35(4):463-7I.

43. Aloulou I, Varlet-Marie E, Mercier J, Brun JF: The hemorheological aspects of the metabolic syndrome are a combination of separate effects of insulin resistance, hyperinsulinemia and adiposity. Clin Hemorheol Microcirc 2006, 35( I-2): I I 3-9.

44. Kleinbongard $P$, Schulz R, Rassaf $T$, Lauer $T$, Dejam A, Jax T, Kumara I, Gharini P, Kabanova S, Ozüyaman B, Schnürch HG, Gödecke A, Weber AA, Robenek M, Robenek H, Bloch W, Rösen P, Kelm M: Red blood cells express a functional endothelial nitric oxide synthase. Blood 2006, 107(7):2943-51.

Publish with Bio Med Central and every scientist can read your work free of charge

"BioMed Central will be the most significant development for disseminating the results of biomedical research in our lifetime. "

Sir Paul Nurse, Cancer Research UK

Your research papers will be:

- available free of charge to the entire biomedical community

- peer reviewed and published immediately upon acceptance

- cited in PubMed and archived on PubMed Central

- yours - you keep the copyright 